\title{
Frequency and Pathogenicity of Dematiaceous Hyphomycetes on Annual Ryegrass Overseeded on Bermudagrass in Mississippi
}

\author{
R. G. Pratt, Research Plant Pathologist, United States Department of Agriculture-Agricultural Research Service, \\ Waste Management \& Forage Research Unit, Mississippi State, MS 39762
}

\begin{abstract}
Pratt, R. G. 2006. Frequency and pathogenicity of dematiaceous hyphomycetes on annual ryegrass overseeded on bermudagrass in Mississippi. Plant Dis. 90:1085-1090.

Fungal diseases of annual ryegrass (Lolium multiflorum Lam.), a cool-season species grown for forage and turf in the southeastern United States, and bermudagrass (Cynodon dactylon (L.) Pers.), a warm-season perennial, usually are considered distinct. In May 2002 and 2004, symptoms of leaf and stem necrosis were observed simultaneously in forage bermudagrass and overseeded annual ryegrass on a swine waste application site in Mississippi. Sporulation by nine species of Bipolaris, Curvularia, Drechslera, and Exserohilum was observed on symptomatic leaves of ryegrass that were surface disinfested and plated on agar each year, and axenic cultures were established by spore transfers. These isolations represent four new worldwide and two new North American records of occurrence of fungal pathogens on ryegrass, and three new records for the southeastern United States and Mississippi. Bipolaris cynodontis, a common bermudagrass pathogen, and Drechslera dictyoides were observed most frequently on ryegrass during both years. In excised leaves of ryegrass inoculated with infested agar discs, most isolates of $B$. cynodontis from ryegrass and bermudagrass were equally virulent and caused necrosis equal to or greater than that caused by $D$. dictyoides, an established ryegrass pathogen. Isolates of $B$. cynodontis from both hosts also caused similar symptoms in foliage of ryegrass and bermudagrass following spore inoculations. Pathogenicity to ryegrass of five other species of dematiaceous hyphomycetes that represented new worldwide or North American records of occurrence also was demonstrated by foliar inoculations. All pathogens were reisolated from symptomatic tissues and grown in axenic culture for fulfillment of Koch's postulates. Results demonstrate that most of the same species of dematiaceous hyphomycetes infect both forage ryegrass and bermudagrass in Mississippi and indicate that $B$. cynodontis, in particular, may be a common and virulent pathogen of ryegrass in the southeastern United States.
\end{abstract}

Bermudagrass (Cynodon dactylon (L.) Pers.), a warm-season, sod-forming perennial (subfamily Chloridoideae), and ryegrass (Lolium multiflorum Lam.), a coolseason annual (subfamily Pooideae), are widely grown both individually and in mixed stands for forage and turf in the southeastern United States $(1,5,12,15)$. In both cropping situations, ryegrass often is overseeded onto bermudagrass sod in late summer, and both species may grow simultaneously for several weeks or months through early fall, until bermudagrass becomes winter dormant. Simultaneous growth of the two species commences again in spring and early summer after bermudagrass breaks dormancy and before annual ryegrass completes its growth cycle.

Despite the common simultaneous growth of annual ryegrass and bermuda-

Corresponding author: R. G. Pratt

E-mail: rpratt@msa-msstate.ars.usda.gov

Accepted for publication 11 April 2006.

DOI: 10.1094/PD-90-1085

This article is in the public domain and not copyrightable. It may be freely reprinted with customary crediting of the source. The American Phytopathological Society, 2006 grass in overseeded pastures and turf in fall and spring in the southeastern United States, fungal diseases usually are considered distinct for the two species, and most pathogens are not reported to infect or seriously damage both grasses simultaneously. Important diseases that occur primarily on annual ryegrass in the Southeast include blast (Magnaporthe grisea (Herbert) Yaegashi \& Udagawa), Pythium blights (Pythium spp.), Rhizoctonia blight (Rhizoctonia solani Kühn), and crown rust (Puccinia coronata Corda) $(2,3,15,16)$. Important diseases that occur primarily on bermudagrass include spring deadspot (Leptosphaeria, Ophiosphaerella, and Gaeumannomyces spp.), bermudagrass decline (Gaeumannomyces graminis (Sacc.) Arx \& D. Olivier var. graminis), dollar spot (Sclerotinia homoeocarpa F. T. Bennett), and Rhizoctonia brown patch $(2,3,14,16)$

Both bermudagrass and ryegrass also are affected by diseases caused by species of Exserohilum, Bipolaris, Curvularia, and Drechslera (collectively referred to here as "dematiaceous hyphomycetes;" 6,11), but the specific pathogens reported to infect the two grasses differ almost entirely. Ryegrass, fescue, bluegrass, and other coolseason grasses or species of north- temperate regions are most commonly parasitized by Bipolaris sorokiniana (Sacc. ex Sorok.) Shoemaker and four species of Drechslera that seldom or never are observed on bermudagrass $(2,4,8,13)$. Bermudagrass, in contrast, usually is considered to be most commonly attacked by $B$. cynodontis (Marig.) Shoemaker $(2,16)$, a pathogen not known to infect ryegrass in North America $(2,4)$. Numerous other species of Exserohilum, Bipolaris, and Curvularia also infect bermudagrass grown for turf or forage $(2,6,7,11)$, and most of these have seldom or never been reported as pathogens of ryegrass. Smiley et al. (14) have summarized in tabular form information on host ranges and importance of genera and species of dematiaceous hyphomycetes on turfgrasses.

In May 2002 and 2004, symptoms of foliar necrosis typical of those caused by dematiaceous hyphomycetes were observed in a mixed stand of actively growing forage bermudagrass and annual ryegrass that had been overseeded on it the previous fall on a swine waste application site in Mississippi. Preliminary observations of sporulation by pathogens on symptomatic tissues indicated that many of the same species were present on both the ryegrass and bermudagrass simultaneously. Therefore, this study was undertaken to establish the identities and frequencies of dematiaceous hyphomycetes on annual ryegrass in the affected stand, prove pathogenicity of species not previously reported to occur on ryegrass worldwide or in North America, compare frequencies of dematiaceous hyphomycetes on symptomatic ryegrass and bermudagrass grown together, and evaluate pathogenicity of isolates of $B$. cynodontis from ryegrass and bermudagrass to both grass hosts.

\section{MATERIALS AND METHODS}

Sampling, identification, isolation, and storage of pathogens from ryegrass and bermudagrass. In May 2002, samples of diseased overseeded common annual ryegrass (no variety designation) and common bermudagrass were collected from throughout each of two randomly designated, 0.4-ha sampling areas on a waste application field (approximately 45 ha) of a commercial swine farm in Clay County, MS. Approximately $\geq 80 \%$ disease incidence was observed among individual ryegrass plants throughout this pasture. Symptoms in individual plants ranged 
from slight necrosis at tips of lower leaves only to complete necrosis of most leaves, with stem and crown rot, stunting, and death of plants. Necrosis always was most severe on lower leaves and usually not present on flag leaves except in the most severely affected plants.

In underlying bermudagrass, red-brown lesions were present in lower leaves that coalesced to form patches of pink-orange to light-brown necrosis in distal blade tissue; these symptoms were identical to those described previously for B. cynodon$t i s$ and other dematiaceous hyphomycete species and complexes $(2,3,6,11,16)$.

In all, 200 symptomatic leaves of ryegrass, 1 leaf per plant, and 200 symptomatic leaves of bermudagrass, 1 leaf per stem, were excised from randomly selected plants and stems in each sampling area and stored in plastic bags with a moist paper towel at $5^{\circ} \mathrm{C}$ for up to 5 days prior to assay.

Ryegrass was not planted on this site in autumn of 2002 to enable wintertime burning of the pasture during 2002-03 for destruction of thatch. Therefore, ryegrass was not present in spring 2003, but it was planted again in fall 2003. In May 2004, foliar symptoms of disease again were observed, but both incidence (approximately $50 \%$ ) and severity on individual plants were less than in 2002. Two hundred symptomatic leaves of ryegrass then were collected from each of the same two sampling areas and in the same manner as in 2002; samples were not collected from bermudagrass in 2004.

Leaf blades of each species were trimmed to $4-\mathrm{cm}$ lengths that included primarily symptomatic tissue with necrosis or necrotic lesions, and also borderlines with healthy-appearing green tissue. Leaf tissues were washed under running tapwater for $30 \mathrm{~min}$, blotted, surface-disinfested in $70 \%$ ethanol for 10 to $15 \mathrm{~s}$ (bermudagrass) or $40 \mathrm{~s}$ (ryegrass), rewashed, blotted, and plated on large (13.5-cmdiameter) plates of $2 \%$ water agar (20 leaves per plate). Plates were incubated under fluorescent plant growth lights (80 mol m $\mathrm{m}^{-2} \mathrm{~s}^{-1}$ intensity, 12-h photoperiod) for 7 to 14 days at 24 to $26^{\circ} \mathrm{C}$.

Species of Bipolaris, Curvularia, Drechslera, and Exserohilum that sporulated on leaves were identified by features of conidia according to descriptions in keys and monographs $(2,13,14)$. For eight of the nine species observed on ryegrass and bermudagrass, the specific morphological features that enabled their practical identification on plated leaf tissue, or mycelium that emanated from it, were described previously (11). These same morphological features also were used to identify the same species of pathogens on both ryegrass and bermudagrass in this study. For the one remaining species not previously encountered, Drechslera dictyoides (Drechs.) Shoemaker, identifica- tions were made on the basis of large, straight, elongate, obclavate, yellow-brown conidia that were unique in appearance and clearly distinct from those of all other species encountered (2).

Single-spore cultures were obtained by transferring conidia from isolation plates to the surface of Difco cornmeal agar (CMA; Difco Laboratories, Detroit) with a sterile needle, streaking, and transferring colonies that originated from single germinated conidia after 12 to $24 \mathrm{~h}$. To store isolates, flasks of sterile wheat and oat grain (6) were inoculated with mycelium, incubated for 16 to 20 days until visibly completely infested, spread on plastic sheets, air dried for 2 days at 24 to $26^{\circ} \mathrm{C}$, and stored at $10^{\circ} \mathrm{C}$. To regenerate colonies, infested grains were placed on CMA.

Excised leaves of ryegrass were incubated on agar in plates and inoculated with mycelial discs of $D$. dictyoides and $B$. cynodontis because isolates of $D$. dictyoides did not produce sufficient spores in culture for conventional spore inoculations of whole plants (9). Previous work showed that differences in virulence of dematiaceous hyphomycetes in bermudagrass are expressed in excised leaves (10). Therefore, these experiments were performed on the presumption that differences in virulence of pathogens also would be expressed in excised leaf tissues of ryegrass, even though evidence to support it was not available.

Excised leaves were inoculated with three isolates of $D$. dictyoides and three each of $B$. cynodontis from ryegrass and bermudagrass, respectively. Leaves (first leaves proximal from flag leaves on flowering plants) from asymptomatic plants in the field were excised at the base of the blade, trimmed to $4 \mathrm{~cm}$ distal from the cut base, and arranged radially on large plates of water agar, 10 leaves per plate. Leaf sections were inoculated by inverting an agar disc, $4 \mathrm{~mm}$ in diameter and cut from the growing margin of a colony on CMA, over the cut distal edge of each leaf as described previously with bermudagrass (10). After plates with inoculated leaf sections were incubated for 4 days under plant growth lights at 24 to $26^{\circ} \mathrm{C}$, the length of continuous necrosis that extended basipetally from the inoculated edge to the nearest green tissue was measured under a dissecting microscope. Each plate was considered a complete block, in which one control (noninfested agar) and the nine fungal isolates were randomized on leaves. Five replicate plates were used in each of two experiments. Means for inoculation treatments were compared by analysis of variance (ANOVA) and use of Fisher's protected least significant difference (LSD) test at $P=0.05$. Results from repeated experiments were combined in ANOVA if heterogeneity of variance and experiment-treatment interactions were not significant at $P=0.05$.
Inoculation of ryegrass and bermudagrass with spores of $B$. cynodontis and evaluation of symptoms. Foliage of plants was inoculated only with spores of $B$. cynodontis because isolates of $D$. dictyoides produced few or no spores on infested wheat and oat grain (6) or on agar media unamended or amended with cellulose substrates (9). Virulence of isolates of $B$. cynodontis from the two grass hosts was compared by inoculating plants of ryegrass and bermudagrass, grown in the greenhouse, with spores atomized onto foliage. To obtain spores, $3 \mathrm{~g}$ of infested wheat and oat grain from each of three isolates of the pathogen from each host (9 $\mathrm{g}$ total per source) were composited and comminuted dry for $10 \mathrm{~s}$ in a commercial food blender (Osterizer; Sunbeam Corp., Boca Raton, FL). Fragmented infested grain (1 g) then was scattered over a large plate of water agar and plates were incubated under the plant growth lights. After 7 to 10 days, numerous spores were present over the surfaces of particles and mycelium that grew from them into surrounding agar. Spores were harvested by pouring $50 \mathrm{ml}$ of a weak sticker solution (Pel-gel, $1.0 \mathrm{~g} / 100$ $\mathrm{ml}$ distilled water; Liphatech Corp., Milwaukee, WI) over the surface of each plate, scraping with a spatula, and filtering through double-layer cheesecloth. Spore suspensions from several plates were combined to give $100 \mathrm{ml}$ after concentrations were adjusted to levels of 1.5 to $2.8 \times 10^{4}$ spores/ml that were uniform within experiments as determined from means of four hemacytometer counts. A total of 100 $\mathrm{ml}$ of each spore suspension then was atomized evenly and simultaneously onto leaves of bermudagrass or ryegrass plants in five or six replicate styrofoam cups. Control plants in five or six cups were sprayed with the sticker solution only. Plants of common bermudagrass and of cv. Gulf ryegrass were grown from seed in commercial potting mixture (Miracle-Gro Lawn Products, Marysville, $\mathrm{OH}$ ) in styrofoam cups (248-ml capacity) in a greenhouse for 35 to 50 and 18 to 20 days, respectively, prior to inoculation at 18 to $30^{\circ} \mathrm{C}$. After inoculation, each cup was sealed individually in a transparent plastic bag with a saturated paper towel to provide $100 \%$ relative humidity. Cups of all treatments were arranged in a randomized complete block design under the plant growth lights and incubated for 3 days to initiate infection and disease development. Bags then were removed, percentages of symptomatic leaf tissue (chlorotic, necrotic, or with lesions) were estimated visually for total foliage in each cup, and cups were removed to the greenhouse and grown in ambient air in the same block arrangements for 7 additional days. Symptom severity then was estimated a second time. Data were compared by ANOVA after arcsin square root transformation of percentages. Results from repeated ex- 
periments were combined if heterogeneity of variance and experiment-treatment interactions were not significant at $P=$ 0.05 , and treatment means were compared by use of Fischer's protected LSD test at $P$ $=0.05$.

Inoculation of ryegrass with other dematiaceous hyphomycetes, evaluation of symptoms, and reisolation of pathogens. For five species of dematiaceous hyphomycetes not previously recorded on ryegrass in North America or worldwide, foliar inoculations were performed to qualitatively evaluate pathogenicity and reisolate pathogens from infected tissue for fulfillment of Koch's postulates. Spore inoculations were performed by the same procedures used with $B$. cynodontis on ryegrass and bermudagrass, except that common annual ryegrass was inoculated in place of cv. Gulf, plants were inoculated at 18 to 32 days after seeding, and spores were collected and applied to plants in dilute water agar $(0.1 \%)$ rather than Pelgel. Pathogenicity was evaluated in repeated individual experiments for each species without adjustment of spore concentrations to similar levels. Inoculum of two or three isolates of each species was combined in each experiment, except that a single isolate was used for $B$. stenospila. Hyphal fragments of this isolate were used to inoculate plants because few conidia were produced from plated infested grain. Mycelium and spores scraped from the surface of three plates in dilute water agar was adjusted to $200 \mathrm{ml}$, comminuted for $20 \mathrm{~s}$, and filtered through four-layer cheesecloth to remove large masses of hyphae. Aliquots of the hyphal suspension were diluted serially to $1 / 1,000,0.1 \mathrm{ml}$ was streaked over plates of Sabouraud's agar plus dextrose and chloramphenicol (Remel Co., Lenexia, KS), and numbers of colonies of $B$. stenospila were counted under a dissecting microscope $(\times 30)$ after 2 and 3 days.

For each experiment with each fungal species, $80 \mathrm{ml}$ of the dilute agar solution containing spores or hyphal fragments were atomized onto foliage of plants in four replicate cups simultaneously in the inoculated treatment, and $80 \mathrm{ml}$ of the agar solution alone were atomized onto plants in four cups for controls. Cups were sealed within plastic bags as with $B$. cynodontis and maintained in randomized complete blocks in shade in the greenhouse for 3 days. Bags then were removed, cups were placed in full sunlight in the same blocking arrangements, and percentages of foliage in each cup with chlorotic, brown, or necrotic foliage were estimated visually for each cup at 3 and 10 days after inoculation.

For each experiment with each fungal species, significant differences in percentages of symptomatic foliage between the inoculated and control treatments $(P=$ 0.05 ) were determined by analysis of vari- ance after arcsin square root transformation of data.

To reisolate pathogens, 10 pieces of symptomatic leaf tissue, 3 to $4 \mathrm{~cm}$ long and with dark elliptical lesions, constricted necrosis, and chlorosis at borders with green tissue, were excised from inoculated plants after 10 days, surface disinfested for $10 \mathrm{~s}$ in $70 \%$ ethanol followed by $20 \mathrm{~s}$ in $1 \% \mathrm{NaOCl}$, rinsed in sterile distillled water, blotted, and plated on water agar. Spores of all species, including $B$. stenospila, developed on leaf tissue and mycelium that emanated from it after 3 to 7 days. Spores of each species were transferred from three leaves with a sterile needle to Difco CMA and observed for axenic growth after $24 \mathrm{~h}$. Hyphae that originated from germinated conidia in the absence of bacteria or other fungi were transferred to obtain new axenic cultures.

\section{RESULTS}

Numbers, identities, and frequencies of dematiaceous hyphomycetous pathogens in ryegrass and bermudagrass leaves. Sporulation by species of dematiaceous hyphomycetes was observed on
$100 \%$ of assayed leaves of bermudagrass in 2002 and on $99.5 \%$ and $94.25 \%$ of assayed leaves of ryegrass in 2002 and 2004, respectively (Table 1). All assayed leaves of bermudagrass, and a majority of leaves of ryegrass during both years, were infected by multiple rather than single pathogens. A maximum of five pathogen species was observed on individual leaves of both ryegrass and bermudagrass. Numbers of ryegrass leaves infected by dematiaceous hyphomycetes, numbers infected by multiple species, and mean numbers of species per leaf were all lower in 2004 than in 2002 (Table 1).

Nine species of dematiaceous hyphomycetous pathogens were observed on symptomatic leaves of ryegrass during both years, and seven were observed on symptomatic leaves of bermudagrass in 2002 (Table 2). Frequencies of individual pathogens varied on both grasses from $1 \%$ to nearly $100 \%$. In 2002 , B. cynodontis was the most frequently observed pathogen on both sampling sites and was present in symptomatic tissues of both grasses at $>90 \%$ frequency. D. dictyoides also was present at high frequencies on ryegrass, but

Table 1. Numbers of species of dematiaceous hyphomycetous pathogens observed to sporulate on leaves of forage ryegrass and bermudagrass during one or two spring growing seasons on a swine waste application site in Mississippi

\begin{tabular}{|c|c|c|c|}
\hline \multirow[b]{3}{*}{ No. of species } & \multicolumn{3}{|c|}{ Year, grass species, and number of leaves ${ }^{y}$} \\
\hline & \multicolumn{2}{|c|}{2002} & \multirow{2}{*}{$\begin{array}{c}2004 \\
\text { Ryegrass }\end{array}$} \\
\hline & Bermudagrass & Ryegrass & \\
\hline 0 & 0 & 2 & 23 \\
\hline 1 & 0 & 39 & 161 \\
\hline 2 & 62 & 71 & 160 \\
\hline 3 & 173 & 119 & 45 \\
\hline 4 & 164 & 52 & 10 \\
\hline 5 & 1 & 17 & 1 \\
\hline $\operatorname{Mean}^{z}$ & 3.26 & 2.58 & 1.65 \\
\hline
\end{tabular}

${ }^{y}$ Numbers of symptomatic leaves out of 400 for each host species during each year on which zero to five species of pathogens were observed to sporulate following surface-disinfestation and plating on agar. No more than five species of pathogens were ever observed to sporulate on any leaf.

${ }^{\mathrm{z}}$ Mean number of pathogens.

Table 2. Identity and frequency of dematiaceous hyphomycetous pathogens on symptomatic leaves of bermudagrass and overseeded ryegrass on a swine waste application site in Mississippi

\begin{tabular}{lccc}
\hline & \multicolumn{3}{c}{$\begin{array}{c}\text { Year, grass species, and number of leaves } \\
\text { on which pathogens were observed }\end{array}$} \\
\cline { 2 - 4 } Pathogen & \multicolumn{2}{c}{$\mathbf{2 0 0 2}$} & $\mathbf{2 0 0 4}$ \\
\cline { 2 - 3 } \cline { 4 - 4 } Bipolaris cynodontis & Bermudagrass & Ryegrass & Ryegrass \\
B. hawaiiensis & $199 \mathrm{a}$ & $184 \mathrm{a}$ & $118 \mathrm{~b}$ \\
B. sorokiniana & $0 \mathrm{~d}$ & $3 \mathrm{c}$ & $1 \mathrm{~d}$ \\
B. spicifera & $1 \mathrm{~d}$ & $24 \mathrm{c}$ & $6 \mathrm{~cd}$ \\
B. stenospila & $105 \mathrm{c}$ & $24 \mathrm{c}$ & $6 \mathrm{~cd}$ \\
Curvularia geniculata & $1 \mathrm{~d}$ & $2 \mathrm{c}$ & $2 \mathrm{~d}$ \\
C. lunata & $0 \mathrm{~d}$ & $1 \mathrm{c}$ & $1 \mathrm{~d}$ \\
Exserohilum rostratum & $145 \mathrm{~b}$ & $52 \mathrm{~b}$ & $5 \mathrm{~cd}$ \\
Drechslera dictyoides & $198 \mathrm{a}$ & $74 \mathrm{~b}$ & $34 \mathrm{c}$ \\
\hline Dannnyy & $1 \mathrm{~d}$ & $171 \mathrm{a}$ & $139 \mathrm{a}$ \\
\hline
\end{tabular}

${ }^{\mathrm{z}}$ Data are mean numbers of pathogens observed on single symptomatic leaves collected from 200 randomly selected plants from each of two sampling areas (0.4 ha) in May 2002 and 2004. Pathogens were identified by microscopic examination of sporulation on surfaces of disinfested leaf sections incubated on water agar under plant growth lights for 7 to 10 days. Means within columns not followed by the same letter differ significantly at $P=0.05$ according to Fisher's protected least significant difference test. 
it was barely detected on bermudagrass. Exserohilum rostratum (Drechs.) Leonard \& Suggs, Curvularia lunata (Wakk.) Boedijn, and B. spicifera (Banier) Subr. All were present at high to very high frequencies on bermudagrass but at much lower frequencies on ryegrass. Other pathogens were present only at low frequencies on either or both grasses.

In 2004, D. dictyoides and B. cynodontis again were the most frequently observed pathogens on ryegrass, and the frequency of $D$. dictyoides was significantly greater than B. cynodontis. All other pathogens were present at much lower frequencies (Table 2).

Pathogenicity of $B$. cynodontis on excised leaves and whole plants of ryegrass and bermudagrass. On excised leaves of ryegrass inoculated with discs of infested agar, isolates of both $B$. cynodontis and $D$. dictyoides induced a similar light-brown necrosis, identical to that observed on plants in the field, that progressed in an irregular front from inoculated tips toward the bases of leaf sections. All isolates of $B$. cynodontis from ryegrass and bermudagrass induced similar levels of necrosis that were equal to or greater than that induced by two of the isolates of $D$. dictyoides (Table 3). A third isolate of $D$. dictyoides induced less necrosis than five isolates of B. cynodontis.

On foliage of whole plants of ryegrass inoculated with spores of B. cynodontis, symptoms differed qualitatively from those observed in bermudagrass. The principal symptoms in ryegrass 3 days after inoculation were chlorosis of lower leaves with medium- to dark-brown necrotic flecks, elliptical lesions, and streaks embedded within. Similar flecks, lesions, and streaks

Table 3. Mean lengths of necrosis induced in excised leaves of annual ryegrass inoculated with isolates of Drechslera dictyoides from ryegrass and of Bipolaris cynodontis from ryegrass and bermudagrass ${ }^{\mathrm{z}}$

\begin{tabular}{|c|c|c|}
\hline $\begin{array}{l}\text { Species, } \\
\text { host of origin }\end{array}$ & Isolate & $\begin{array}{l}\text { Mean length of } \\
\text { necrosis (mm) }\end{array}$ \\
\hline $\begin{array}{l}\text { None (control) } \\
\text { D. dictyoides }\end{array}$ & & $3.1 \mathrm{e}$ \\
\hline \multirow{3}{*}{ Ryegrass } & 1 & $17.7 \mathrm{a}$ \\
\hline & 2 & $11.4 \mathrm{~cd}$ \\
\hline & 3 & $7.5 \mathrm{de}$ \\
\hline \multicolumn{3}{|l|}{ B. cynodontis } \\
\hline \multirow[t]{3}{*}{ Ryegrass } & 1 & $15.4 a b c$ \\
\hline & 2 & $16.6 \mathrm{abc}$ \\
\hline & 3 & $12.0 \mathrm{bcd}$ \\
\hline \multirow[t]{3}{*}{ Bermudagrass } & 1 & $17.3 \mathrm{ab}$ \\
\hline & 2 & $15.8 \mathrm{abc}$ \\
\hline & 3 & $16.2 \mathrm{abc}$ \\
\hline \multicolumn{3}{|c|}{$\begin{array}{l}{ }^{\mathrm{z}} \text { Mean lengths of continuous necrosis in } 4-\mathrm{cm} \\
\text { sections of ryegrass leaf blades incubated on } \\
\text { plates of agar } 4 \text { days after tips were inoculated } \\
\text { with mycelium. Means based on combined } \\
\text { results from two experiments with five repli- } \\
\text { cate leaves per experiment. Means not fol- } \\
\text { lowed by the same letter differ significantly at } \\
P=0.05 \text { according to Fischer's protected least } \\
\text { significint difference test }\end{array}$} \\
\hline
\end{tabular}

also were present in nonchlorotic green tissue. Only lowermost leaves and tips of upper leaves of inoculated ryegrass plants were completely necrotic 3 days after inoculation. In bermudagrass, in contrast, which forms thinner and finer leaves, partial to complete light-brown necrosis of leaves was the predominant symptom 3 days after inoculation, and chlorosis of leaf tissue was minimal. In ryegrass plants 10 days after inoculation, numerous lesions had enlarged and coalesced to form extensive necrosis, and chlorosis then was absent or minimal. Red-brown, elongate lesions and streaks were still present within both light-pink to orange-brown necrotic and green tissues of ryegrass 10 days after inoculation. In bermudagrass 10 days after inoculation, lower leaves often were completely necrotic and shriveled, and individual necrotic lesions were present within green tissues of upper leaves.

In uninoculated control plants of both ryegrass and bermudagrass, the oldest, lowermost leaves often became uniformly chlorotic or necrotic during experiments without embedded necrotic flecks, lesions, or streaks, and without constricting necro-

Table 4. Severity of foliar symptoms in annual ryegrass and bermudagrass after inoculation with spores of Bipolaris cynodontis from bermudagrass and ryegrass at equal concentrations ${ }^{\mathrm{x}}$

\begin{tabular}{|c|c|c|}
\hline \multirow[b]{2}{*}{ Species, host $^{\mathrm{z}}$} & \multicolumn{2}{|c|}{$\begin{array}{c}\text { Mean foliage (\%) with } \\
\text { symptoms at days after } \\
\text { spore inoculations }\end{array}$} \\
\hline & 3 days & 10 days \\
\hline \multicolumn{3}{|l|}{ Ryegrass } \\
\hline None (control) & $1 \mathrm{~b}$ & $4 \mathrm{~b}$ \\
\hline Ryegrass & $26 \mathrm{a}$ & $31 \mathrm{a}$ \\
\hline Bermudagrass & $27 \mathrm{a}$ & $32 \mathrm{a}$ \\
\hline \multicolumn{3}{|l|}{ Bermudagrass } \\
\hline None (control) & $15 \mathrm{~b}$ & $18 \mathrm{~b}$ \\
\hline Ryegrass & $50 \mathrm{a}$ & $41 \mathrm{a}$ \\
\hline Bermudagrass & $48 \mathrm{a}$ & $45 \mathrm{a}$ \\
\hline
\end{tabular}

${ }^{x}$ Plants of ryegrass cv. Gulf, grown for 2.5 weeks from seed in styrofoam cups, were inoculated by atomizing equal quantities of spores $\left(28 \times 10^{3} / \mathrm{ml}\right)$ of three combined isolates from each source host onto foliage and incubating in a saturated atmosphere under plant growth lights at 24 to $26^{\circ} \mathrm{C}$ for 3 days. Cups then were removed to the greenhouse and grown in ambient air at 25 to $30^{\circ} \mathrm{C}$ for 7 additional days. Plants of common bermudagrass were grown (5 weeks), inoculated $(18 \times$ $10^{3}$ spores $/ \mathrm{ml}$ ), and incubated similarly in separate experiments.

${ }^{y}$ Means based on visual estimates of percentages of foliage with chlorosis, necrosis, or lesions in five replicate cups in each of two combined experiments with ryegrass and in six replicate cups in each of two combined experiments with bermudagrass. Symptoms in controls did not include lesions and appeared to represent senescence of lower leaves. Means within columns for each grass species not followed by the same letter differ significantly at $P=0.05$ according to Fisher's protected least significant difference test.

${ }^{\mathrm{z}}$ Species inoculated and B. cynodontis host of origin. sis of terminal leaf blades. These symptoms in controls appeared to result from senescence of lower leaves rather than pathogenesis. They were induced or enhanced during incubation of plants in saturated atmospheres for 3 days and usually were more severe in bermudagrass than in ryegrass.

The three composited isolates of $B$. cynodontis from each of ryegrass and bermudagrass induced symptoms of similar severity in leaves of ryegrass plants 3 and 10 days after inoculation with spore suspensions, and also in leaves of bermudagrass inoculated and evaluated in the same manner in separate experiments (Table 4).

Pathogenicity of other species of dematiaceous hyphomycetes on whole plants of ryegrass. Five other species of dematiaceous hyphomycetes, that represented new North American or worldwide records of occurrence on ryegrass, all incited similar symptoms in inoculated plants that differed qualitatively and quantitatively from controls in one or both experiments. Qualitative symptoms observed in inoculated plants but not controls were small, oval to elliptical, red-brown to grayblack flecks and lesions approximately 2 to $3 \mathrm{~mm}$ long. Lesions were most evident on lower leaves at both 3 and 10 days after inoculation and were present within both green and necrotic tissues. No differences in size, color, or appearance of lesions were noted among plants inoculated with the five fungal species. Qualitative symptoms also included necrotic girdling, and constriction and shriveling of lower leaves that commonly commenced at tips and progressed basipetally as in large plants in the field. Plants in control cups manifested various degrees of chlorosis and browning of lower leaves, as in experiments with $B$. cynodontis. These symptoms increased with plant age, but leaves of control plants usually did not develop necrotic flecks, lesions, or streaks, or constricting, basipetally progressive necrosis, as in inoculated plants. Qualitative symptoms on whole leaves usually were similar for the five species of pathogens, except that $B$. hawaiiensis induced a more pronounced, golden-yellow chlorosis on infected lower leaves than did the other species.

Significant quantitative differences between inoculated and control plants in percentage of chlorotic and necrotic leaf tissues 3 and 10 days after inoculation also were observed for all pathogens in one or both experiments (Table 5). Comparisons were not be made between species or experiments because inoculum concentrations and ages of plants differed.

Sporulation by all pathogens was observed on symptomatic leaves that were surface disinfested and plated on water agar. In all instances, only sporulation by the pathogen applied as inoculum was observed on leaves. Spores of all pathogens germinated after transfer from two or more 
leaves, and axenic cultures of each species were established by transfer of hyphae from spores that germinated in the absence of bacterial or fungal contamination.

\section{DISCUSSION}

Annual ryegrass and bermudagrass are the two most common, widespread, and economically important cool-season annual and warm-season perennial grasses, respectively, that are grown for forage and turf in the southeastern United States $(1,5,12)$. Fungal diseases on these species usually are considered distinct, with little or no cross-infection or epidemiological relationships between them $(2,14,16)$. Bermudagrass in the southeastern United States and elsewhere is parasitized by numerous species of Bipolaris, Curvularia, and Exserohilum $(2,4,11)$, but no true species of Drechslera (13) other than D. gigantea (Heald and Wolf) Ito $(2,11)$ are reported to parasitize bermudagrass (4). In contrast, ryegrass is widely reported as a host of four true Drechslera spp. in the southeastern United States (4), but only a few sporadic reports from diverse locations in the world have indicated occurrence of species of Bipolaris (other than B. sorokiniana), Curvularia, and Exserohilum on ryegrass (4). Therefore, results of this study establish, for the first time, that all eight species of Bipolaris, Curvularia, and Exserohilum that are known to parasitize bermudagrass in Mississippi (11) also may occur commonly on symptomatic leaves of annual ryegrass when this species is grown as an overseeded crop on a dormant bermudagrass turf. Five of these eight species, that represent new North American and world records of occurrence, were demonstrated to be pathogenic to ryegrass seedlings in greenhouse inoculation tests. Therefore, these repeated field observations and inoculation experiments leave no doubt that all species of Bipolaris, Curvularia, and Exserohilum known to infect bermudagrass in Mississippi also infect annual ryegrass when these two hosts are grown together.

Results of this study suggest that $B$. cynodontis is likely to be the most important of the new species of dematiaceous hyphomycetes on ryegrass in Mississippi and possibly other areas of the southeastern United States. In 2002, it was the species most frequently observed on leaves of both bermudagrass and ryegrass and, in 2004, it was the second-most-frequent species observed on ryegrass. In each year, incidence of $B$. cynodontis was significantly higher than for all other species of
Bipolaris, Curvularia, and Exserohilum that were newly observed on ryegrass in this region (Table 2).

Along with its high frequency of occurrence, most isolates of $B$. cynodontis from both ryegrass and bermudagrass also were equally or more virulent on excised leaves of mature ryegrass than isolates of $D$. dictyoides, a long-recognized ryegrass pathogen (Table 3). Virulence of these two species was compared by inoculation of excised leaf tissues with mycelial discs (Table 3) because $D$. dictyoides did not form conidia in culture to enable foliar inoculations with spores. These experiments were performed on the presumption that symptom development in excised leaf tissues of ryegrass would correspond to virulence of pathogens or host resistance as demonstrated previously for bermudagrass (10). Validity of this presumption is supported by the fact that the virulence of $B$. cynodontis manifested initially in excised leaf tissues of ryegrass later was confirmed by foliar inoculations of whole plants with conidia (Table 4).

On foliage of bermudagrass, isolates of $B$. cynodontis from ryegrass and bermudagrass were equally virulent when applied at similar spore concentrations. Therefore, these results indicate that isolates of $B$.

Table 5. Pathogenicity of five species of Bipolaris, Curvularia, and Exserohilum, newly observed on ryegrass worldwide or in North America, on ryegrass seedlings following inoculation of leaves with spores or hyphal fragments

\begin{tabular}{|c|c|c|c|c|c|}
\hline \multirow[b]{2}{*}{ Fungus, experiment } & \multirow[b]{2}{*}{ Treatment } & \multirow[b]{2}{*}{ Form of inoculum ${ }^{y}$} & \multirow[b]{2}{*}{ Inoculum (spores or $\left.\mathrm{CFU} \times 10^{3} / \mathrm{ml}\right)^{\mathrm{z}}$} & \multicolumn{2}{|c|}{$\begin{array}{l}\text { Mean foliage symptomatic at days } \\
\text { postinoculation }(\%)^{\mathrm{x}}\end{array}$} \\
\hline & & & & 3 days & 10 days \\
\hline \multicolumn{6}{|l|}{ Bipolaris hawaiiensis } \\
\hline \multirow[t]{2}{*}{1} & Inoculated & Conidia & 94 & $9 *$ & 11 \\
\hline & Control & None & 0 & 0 & 7 \\
\hline \multirow[t]{2}{*}{2} & Inoculated & Conidia & 52 & $22 *$ & $14 *$ \\
\hline & Control & None & 0 & 1 & 6 \\
\hline \multicolumn{6}{|l|}{ B. spicifera } \\
\hline \multirow[t]{2}{*}{1} & Inoculated & Conidia & 153 & $5 *$ & $10 *$ \\
\hline & Control & None & 0 & 1 & 4 \\
\hline \multirow[t]{2}{*}{2} & Inoculated & Conidia & 126 & 12 & 13 \\
\hline & Control & None & 0 & 9 & 9 \\
\hline \multicolumn{6}{|l|}{ B. stenospila } \\
\hline \multirow[t]{2}{*}{1} & Inoculated & Hyphal fragments & 70 & $39 *$ & $15 *$ \\
\hline & Control & None & 0 & 6 & 8 \\
\hline \multirow[t]{2}{*}{2} & Inoculated & Hyphal fragments & 50 & $19 *$ & $19 *$ \\
\hline & Control & None & 0 & 12 & 7 \\
\hline \multicolumn{6}{|l|}{ Curvularia geniculata } \\
\hline \multirow[t]{2}{*}{1} & Inoculated & Conidia & 286 & $7 *$ & $14 *$ \\
\hline & Control & None & 0 & 1 & 4 \\
\hline \multirow[t]{2}{*}{2} & Inoculated & Conidia & 254 & $11 *$ & $15 *$ \\
\hline & Control & None & 0 & 4 & 9 \\
\hline \multicolumn{6}{|l|}{ Exserohilum rostratum } \\
\hline \multirow[t]{2}{*}{1} & Inoculated & Conidia & 14 & $3 *$ & 14 \\
\hline & Control & None & 0 & 0 & 9 \\
\hline \multirow[t]{2}{*}{2} & Inoculated & Conidia & 10 & $10 *$ & 14 \\
\hline & Control & None & 0 & 3 & 8 \\
\hline
\end{tabular}

${ }^{\mathrm{x}}$ Means based on visual estimates of percentages of foliage with symptoms of chlorosis, necrosis, and for lesions in four replicate cups of each treatment. Symptoms in controls did not include lesions and appeared to represent senescence of lower leaves. For each experiment within each fungal species, asterisks $(*)$ indicate that means of inoculated plants differ significantly from controls at $P=0.05$ according to Fisher's protected least significant difference test.

${ }^{y}$ Inoculum was obtained from colonies grown for 4 to 7 days from particles of dried and blended mixtures of infested wheat and oat grain scattered on plates of water agar $(13.5 \mathrm{~cm}$ in diameter). Dilute $(0.1 \%)$, liquid agar $(35$ to $50 \mathrm{ml})$ was added to the surface of each plate and spores and mycelium were scraped into suspension with a spatula. Conidia were obtained by filtering suspensions through cheesecloth to remove mycelium. Where few or no conidia were present, suspensions were comminuted in a blender and filtered through cheesecloth to obtain suspensions of hyphae.

${ }^{\mathrm{z}}$ Estimated concentrations of conidia used in inoculum are means of four hemacytometer counts. Estimated concentrations of viable hyphal fragments are mean numbers of colonies observed on three plates of Sabouraud's agar plus dextrose and chloramphenicol 3 days after plating of aliquots from serial dilutions $\left(1 \times 10^{3}\right)$ of inoculum suspensions. 
cynodontis from ryegrass and bermudagrass exhibit no evidence of host specialization in pathogenicity. This suggests that there may be no impediment to crossinfection and interchange of inoculum of B. cynodontis between these two grass hosts in the field. An ability of this pathogen to freely cross-infect between two hosts that commonly are grown in close association or in mixed stands in the field should greatly increase its likelihood of causing significant damage in either or

Although B. cynodontis was the most frequent new species of dematiaceous hyphomycete observed on ryegrass in the southeastern United States in this study, six additional species of Bipolaris, Curvularia, and Exserohilum also were observed for the first time on ryegrass in this region (Tables 2 and 6). Although their frequencies of occurrence were lower than for $B$. cynodontis and $D$. dictyoides, all of these species that were inoculated onto ryegrass plants caused similar qualitative symptoms of lesion formation, girdling, and necrotic constriction of leaves in all experiments. Most also caused significant increases in chlorosis and necrosis of foliage in both inoculation experiments, and all were reisolated from surface-disinfested ryegrass leaves. Therefore, this demonstrated evidence for pathogenicity indicates that any or all of these other species also may cause or contribute to significant disease development on ryegrass in the field. On the basis of results of a 3-year sampling study on identities and frequencies of dematiaceous hyphomycetes on forage bermudagrass in Mississippi, it recently was concluded that these pathogens and diseases occur on bermudagrass mainly as complexes rather than individually (11). Results of this study provide strong evidence to further support this conclusion. Species of dematiaceous hyphomycetes were observed on $100 \%$ of 400 symptomatic leaves of bermudagrass in 2002 , sporulation by multiple species was observed on each leaf, and the mean number both of them.

of pathogens observed per leaf was 3.26 (Table 1). On ryegrass, the preponderance of evidence suggests that dematiaceous hyphomycetes also may occur primarily as complexes rather than individual species, but evidence for this conclusion is not as strong as for bermudagrass. In 2002 and 2004 , sporulation by single pathogens was observed in 10 and $40 \%$, respectively, of 400 leaves of ryegrass, and mean numbers of pathogens per leaf were 2.58 and 1.65 , respectively. However, many plants of ryegrass with multiple pathogens manifested sporulation only by the two most common species, B. cynodontis and $D$. dictyoides. Therefore, dematiaceous hyphomycetous diseases on ryegrass more likely may be caused by single pathogens than are such diseases on bermudagrass, but evidence to date still indicates that multiple pathogens occur in a majority of symptomatic plants.

Wintertime burning of dormant bermudagrass pastures is conducted to remove surface thatch and improve plant growth and yield in following years (1). Observations of this study suggest that this practice also may provide cultural control of diseases caused by dematiaceous hyphomycetes in overseeded ryegrass. Although results were not compared statistically between years, the incidence and severity of symptoms observed on plants in the field and numbers of pathogens observed in symptomatic leaves (Tables 1 and 2) appeared to be conspicuously less in 2004 , approximately 16 months after midwinter burning of the pasture, than in 2002, when burning had not been conducted for at least 4 years previously. It is not known whether reduced disease incidence, disease severity, and numbers of pathogens in symptomatic tissue observed in 2004 represent normal yearly variation or effects of the field burning. However, if infection by dematiaceous hyphomycetes is initiated partly from infested thatch (15), especially in annual species such as ryegrass, then reducing or eliminating thatch prior to planting should provide some measure of

Table 6. New records of occurrence and pathogenicity of dematiaceous hyphomycetes on ryegrass ${ }^{\mathrm{z}}$

\begin{tabular}{ll}
\hline Pathogen & \multicolumn{1}{c}{ New records } \\
\hline Bipolaris cynodontis & First record of occurrence on ryegrass in North America \\
B. hawaiiensis & First demonstration of pathogenicity \\
& First record of occurrence on ryegrass worldwide \\
B. sorokiniana & First demonstration of pathogenicity \\
B. spicifera & First record of occurrence on ryegrass in Mississippi \\
& First record of occurrence on ryegrass in North America \\
B. stenospila & First demonstration of pathogenicity \\
& First record of occurrence on ryegrass worldwide \\
Curvularia geniculata & First demonstration of pathogenicity \\
& First record of occurrence on ryegrass worldwide \\
C. lunata & First demonstration of pathogenicity \\
Drechslera dictyoides & First record of occurrence on ryegrass in southeastern United States \\
Exserohilum rostratum & First record of occurrence on ryegrass in southeastern United States \\
& First record of occurrence on ryegrass worldwide \\
& First demonstration of pathogenicity
\end{tabular}

${ }^{\mathrm{z}}$ New records described in this article compared with information presented in Farr et al. (4) as of 21 December 2005. cultural disease control. Further research is needed to evaluate use of wintertime burning of pastures for cultural control of diseases caused by dematiaceous hyphomycetes in both ryegrass and bermudagrass in the southeastern United States.

Further research also is needed to determine whether the dematiaceous hyphomycetous pathogens observed here also occur on ryegrass planted in prepared seedbeds in the absence of bermudagrass, whether infection of ryegrass by $B$. cynodontis and other dematiaceous hyphomycetes significantly reduces forage yield, and whether such infection commonly occurs in overseeded bermudagrass turf as in pastures.

\section{LITERATURE CITED}

1. Burton, G. W., and Hanna, W. W. 1985. Bermudagrass. Pages 247-254 in: Forages: The Science of Grassland Agriculture, 4th ed. M. E. Heath, R. L. Barnes, and D. S. Metcalfe eds. Iowa State University Press, Ames.

2. Couch, H. B. 1995. Diseases of Turfgrasses, 3rd ed. Krieger Publishing Co., Malabar, FL.

3. Couch, H. B. 2000. The Turfgrass Disease Handbook. Krieger Publishing Co., Malabar, FL.

4. Farr, D. F., Rossman, A. Y. Palm, M. E., and McCray, E. G. Fungal Databases, Systematic Botany and Mycology Laboratory, ARS-USDA. Online publication. Retrieved 12/21/05.

5. Hanson, A. A., and Juska, F. V. 1969. Turfgrass Science. American Society of Agronomy, Madison, WI

6. Pratt, R. G. 2000. Diseases caused by dematiaceous fungal pathogens as potential limiting factors for production of bermudagrass on swine effluent application sites. Agron. J. 92:512-517.

7. Pratt, R. G. 2001. Occurrence and virulence of Bipolaris hawaiiensis on bermudagrass (Cynodon dactylon) on poultry waste application sites in Mississippi. Plant Dis. 85:1206.

8. Pratt, R. G. 2003. First report of infection of bermudagrass by Bipolaris sorokiniana in the Southeastern United States. Plant Dis. $87: 1265$.

9. Pratt, R. G. 2003. Comparative sporulation of dematiaceous hyphomycetes on agar media and its enhancement by growth on cellulose substrates. (Abstr.) Phytopathology 93:S72.

10. Pratt, R. G. 2003. An excised-leaf inoculation technique for evaluating host-pathogen interactions and quantitative resistance of bermudagrass genotypes to dematiaceous hyphyomycetes. Phytopathology 93:1565-1571.

11. Pratt, R. G. 2005. Variation in occurrence of dematiaceous hyphomycetes on forage bermudagrass over years, sampling times, and locations. Phytopathology 95:1183-1190.

12. Riewe, M. E., and Mondart, C. L., Jr. 1985. The ryegrasses. Pages 241-246 in: Forages: The Science of Grassland Agriculture, 4th ed. M. E. Heath, R. L. Barnes, and D. S. Metcalfe, eds. Iowa State University Press, Ames.

13. Sivanesan, A. 1987. Graminicolous species of Bipolaris, Curvularia, Drechslera, Exserohilum and their teleomorphs. Mycol. Pap. No. 158. CAB International Mycological Institute, Kew, Surrey, England.

14. Smiley, R. W., Dernoeden, R. H., and Clarke, B. B. 1992. Compendium of Turfgrass Diseases. American Phytopathological Society Press, St. Paul, MN.

15. Trevathan, L. E., Moss, M. A., and Blasingame, D. 1994. Ryegrass blast. Plant Dis. 75:113-117.

16. Vargas, J. M., Jr. 1994. Management of Turfgrass Diseases, 2nd ed. CRC Press, Boca Raton, FL. 